Jurnal Pemikiran Sosiologi Volume 5 No. 2, Agustus 2018

\title{
Giddens dan Kapitalisme: Etika Kerja Buruh Perkebunan Karet di Sumatera Selatan1
}

\author{
Rica Arvenia, Muhammad Fedryansyah. M. Fadhil Nurdin²
}

\begin{abstract}
Abstraksi
Industri karet berkaitan pada kondisi buruh dan penguasaan wilayah, serta masuknya sistem kapitalisme dalam sektor perkebunan karet. Modernitas yang terjadi menjadi beban bagi buruh kerja perkebunan karet karena sistem-sistem modern telah masuk dan dimiliki oleh sistem kapitalisme, sehingga menjadi dampak buruk bagi buruh, kesejahteraan merupakan bagian terpenting dalam sektor industri maupun perkebunan. Artikel ini berfokus pada masalah kapitalisme dan etika kerja yang ada pada perkebunan karet di Sumatera Selatan, dengan menggunakan pendekatan kualitatif dan analisis deskriptif.Teknik pengumpulan data berupa studi literatur, jurnal, observasi, serta wawancara mendalam pada pemilik kebun karet dan buruh perkebunan karet. Hasil penelitian menunjukkan bahwa: (1) terjadinya sistem kapitalisme pada perkebunan karet yang diakibatkan oleh ketikstabilan harga. (2) etika kerja pada perkebunan karet direproduksi oleh perorangan, (3) terjadinya modernitas memberikan dampak pada harapan buruh perkebunan dan menjadi beban bagi pemilik untuk mensejahterahkan buruh. Dalam teori strukturisasi yang dikemukakan oleh Giddens ialah bahwa perubahan struktur dipengaruhi oleh agen dan struktur sehingga kunci utama dari kesejahteraan ada pada sistem, sistem yang tidak baik dapat membawa dampak yang buruk
\end{abstract}

Kata kunci: kapitalisme, modernitas, etika kerja, perkebunan karet

\begin{abstract}
The rubber industry relates to the labor conditions and territorial control, and the entry of capitalism system in the rubber plantation sector. The presence of modernity is a burden for workers in rubber plantations, due to the modern system is owned by capitalism system, so that it causes a bad impact especially to the worker's welfare. This article focuses on the problem of capitalism and the work ethic which exist in the rubber plantation in South Sumatera Province. As for, in this research, author uses qualitative approach and descriptive analysis. The data collection technique used in this research is in the form of literature, journal, observation, and deep interview to the owners of rubber plantation and their workers. The results show that: 1) The occurrence of capitalist system in the rubber plantation is caused by price instability, 2) The work ethic in the rubber plantation is reproduced by individuals, 3) The occurrence of modernity caused a bad impact to the worker's hopefulness and becomes a burden to the rubber plantations owners for the welfare of their workers. In structuration theory put forward by Giddens stated that the structural changes are affected by agent and structure, so that the key solution to welfare is in the system, where the bad system will cause a bad impact.
\end{abstract}

Keywords: capitalism, modernity, rubber plantation, work ethics

\footnotetext{
${ }^{1}$ Untuk mengutip artikel ini: Arvenia, Rica, Fedryansyah, Muhammad, Nurdin, F Fadhil. 2018. "Giddens dan Kapitalisme: Etike Kerja Buruh Karet di Perkebunan Sumatera Selatan." Jurnal Pemikiran Sosiologi 5 (2): 108125

${ }^{2}$ Program Studi Sosiologi Program Pascasarjana, UNPAD. Contact: ricaarvenia@gmail.com
} 
Jurnal Pemikiran Sosiologi Volume 5 No. 2, 2018

Giddens dan Kapitalisme: Etika Kerja Buruh Karet di Perkebunan Sumatera Selatan

Rica Arvenia, Muhammad Fedryansyah, M. Fadhil Nurdin

\section{A. Pendahuluan}

Pekerjaan merupakan bagian penting yang dibutuhkan setiap orang, dengan bekerja dapat membantu perekonomian keluarga memenuhi kebutuhan sehari-hari dan mengasah kemampuan yang dimiliki. Era globalisasi saat ini persaingan kerja sangat susah, bertambahnya jumlah penduduk setiap tahun membuat persaingan semakin ketat, lapangan pekerjaan yang terbatas tak jarang membuat masyarakat kesulitan mendapatkan pekerjaan bahkan banyak sarjana menjadi pengangguran. Indonesia mengalami suatu masalah besar yang tidak bisa dituntaskan yaitu lapangan pekerjaan, masih banyaknya rakyat Indonesia yang menjadi pengemis dan kalaparan. Wajah Indonesia seharusnya bisa diperbaiki dengan pemimpin yang berkualitas.

Kapitalisme merupakan sistem ekonomi politik yang didasarkan pada hak milik pribadi dimana dalam kapitalisme terdapat tujuan kepentingan pribadi tanpa menghargai kebutuhan masyarakat dan menghormati kepentingan umum. Namun dengan adanya sistem kapital ini menjadikan masyarakat lebih bersemangat untuk bekerja, melatih untuk lebih kreatif dalam menjalankan usahanya. Indonesia mempunyai banyak sekali industri akan tetapi sistem industri tidak terlepas oleh kapitalisme, kapitalisme sangat diterapkan pada sistem industri kapitalisme tidak bisa dihindarkan karena sudah menjadi ciri khas dari pemilik modal. Pada sektor perkebunan karet yang ada di Sumatera Selatan memang yang bekerja di perkebunan ada buruh tua dan buruh muda, mereka bekerja di perkebunan karena tidak adanya pilihan pekerjaan lain di Desa. Desa yang ada di Sumatera Selatan identik dengan pertanian dan perkebunan karena sangat cocok untuk bercocok tanam. Bekerja pada perkebunan memang tidak bisa dijanjikan pendapatannya, pendapatan hanya bergantung pada hasil panen dan harga dari komoditi karet. Sistem kerja ini juga sebenarnya dibentuk atas perjanjian antara buruh dan pemilik tidak ada aturan khusus seperti bekerja dikantor, akan tetapi hal seperti ini akan semakin sulit karena keadaan hanya bergantung pada pemilik perkebunan, sistem meminjam uang yang selalu dikembangkan dalam sektor perkebunan karena menunggu hasil panen yang terkadang tidak bisa harian melainkan mingguan dan bulanan.

Rendahnya tingkat pendidikan di desa membuat masyarakat mudah untuk dipengaruhi, masyarakat desa mudah merasa puas akan hasil yang didapat sehingga keadaan seperti ini menyebabkan kepercayaan diri seseorang melemah. Harga karet tidak stabil membuat buruh dan pemilik perkebunan lokal tidak mempunyai semangat bekerja bahkan beberapa pemilik harus 
Jurnal Pemikiran Sosiologi Volume 5 No. 2, 2018

Giddens dan Kapitalisme: Etika Kerja Buruh Karet di Perkebunan Sumatera Selatan

Rica Arvenia, Muhammad Fedryansyah, M. Fadhil Nurdin

memutar modal untuk mendapat keuntungan dan membuat lahan perkebunan karet berubah menjadi perkebunan singkong dll. Usaha semacam ini merupakan cara bertahan hidup agar dapat memenuhi kebutuhan. Hampir 70\% masyarakat Sumatera Selatan bergantung pada hasil perkebunan karet. Masyarakat pedesaan mudah untuk dipengaruhi, pemilik modal selalu ingin menguasai tempat yang berpotensi menguntungkan bagi mereka. Keadaan seperti ini akan membuat masyarakat desa tidak percaya diri sehingga agen dan agensi dapat leluasa untuk mempengaruhi dan dipengaruhi.

\section{B. Tinjauan Pustaka: Konstruksi Teori Strukturasi dari Giddens}

Membahas tentang Anthony Giddens ia adalah seorang ilmuwan sosial kelas dunia yang menjadi dosen tetap sosiologi di Universitas of Cambridge. Sebagai seorang ilmuan Giddens tidak hanya melahirkan karya-karya yang luar biasa bagusnya dan bermutu, akan tetapi ia juga merupakan seorang pemikir yang produktif. Lebih dari 200an judul artikel yang ditulisnya tersebar di jurnal-jurnal professional. Bagian ini akan diarahkan untuk memahami bagaimana konsepsi-konsepsi yang ada pada perkebunan karet serta buruh kerja perkebunan karet. Strukturasi dan agensi menurut Anthony Giddens yang dimaksud struktur adalah "rules dan sources"yang dipakai pada produksi dan reproduksi sistem. Giddens dipandang sebagai orang yang pertama yang menghasilkan teori yang menghubungkan struktur dan agensi, yaitu "teori struktur" dalam teori ini struktur dan agensi tidak dipandang sebagai sebagai dua hal yang terpisah, karena jika demikian akan muncul dualisme struktur agensi. Struktur menurut Giddens harus dipandang sebagai dualitas atau dua sisi yang sama.

Hubungan diantara keduanya sangat berkaitan erat atau dialektik dalam artian struktur dan agensi bersifat saling mempengaruhi dan hal ini berangsur terus menerus. Teori Giddens strukturasi didasarkan pada premis bahwa "The constitution of agents and structures are not two independently given sets of phenomena, a dualism, but represent a duality the structureal properties of social system are both medium and outcome of the practices they recursively organize the moment of the production of action is also one of reproduction in the contexts of the day to day enactment of social life" (Giddens, 1984; dalam Hidayat, 2000:440).

Pada teori strukturasi, isu-isu yang menjadi perhatian utama adalah yang berhubungan dengan hakikat tindakan sosial dan tindakan itu sendiri, bagaimana interaksi itu 
Jurnal Pemikiran Sosiologi Volume 5 No. 2, 2018

Giddens dan Kapitalisme: Etika Kerja Buruh Karet di Perkebunan Sumatera Selatan

Rica Arvenia, Muhammad Fedryansyah, M. Fadhil Nurdin

dikoseptualisasikan dan hubungannya dengan

lembaga-lembaga kemudian memahami

konotasi-konotasi praktis analisis sosial.

Menurut teori strukturasi, bukanlah pengalaman aktor individual atau bentukbentuk kesatuan sosial tertentu, melainkan praktik sosial yang diatur melintasi ruang dan waktu. (Giddens dalam Ritzer,2012). Teori strukturasi bertujuan untuk mengintegrasikan antara agen dan struktur, hubungan keduanya bukan sebatas mempengaruhi dan dipengaruhi akan tetapi hubungan mereka didasarkan pada bahwa struktur itu selalu membebaskan dan mengekang (enabling dan constraining).

Modernitas mengacu kepada bentuk kehidupan sosial atau organisasi yang muncul di Eropa pada kira-kira abad ke-17 dan sesudahnya dan yang pada gilirannya menancapkan pengaruhnya ke seluruh dunia. Cara hidup dari modernitas telah membersihkan kita dari semua jenis tatanan sosial tradisional, dengan cara yang tidak pernah ada sebelumnya. Dalam hal eksistensionalitas maupun intensionalitasnya, transformasi yang berlangsung di dalam modernitas lebih menonjol ketimbang sebagian besar karakteristik perubahan periode sebelumnya. Pengaruh jangka panjang evolusionisme sosial adalah salah satu alasan mengapa karakter diskontinu modernitas sering kali tidak begitu diapresiasi sepenuhnya. Bahkan teori-teori yang menekankan arti penting transisi diskontinu, seperti teori Marx, melihat sejarah manusia mengarah pada satu titik, diatur oleh berbagai prinsip dinamis umum. Sosiologi adalah subjek yang begitu luas dan beragam, sehingga segala segala generalisasi sederhana atasnya sungguh layak dipertanyakan.

Tatanan sosial modernitas yang baru muncul bersifat kapitalis dalam sistem ekonominya dan dalam institusi lainnya. Sudut pandang ini dikritik oleh Durkheim dan Weber, yang membantu merintis interpretasi tandingan yang telah banyak mempengaruhi analisianalisis sosial berikut. Dalam tradisi SainSimon, Durkheim melacak sifat institusi modern terutama pada dampak industrialism. Weber berbicara tentang "kapitalisme, agar berguna bagi eksistensi tatanan industrial, namun dalam beberapa hal kunci pandangannya lebih dekat kepada Durkheim daripada Marx "Kapitalisme rasional" sebagaimana dikatakan weber, mencakup mekanisme ekonomi yang secara khusus disebutkan Marx, termasuk komodifikasi kerja upahan. Karakteristik industrialism adalah pemakaian sumber-sumber kekuasaan material yang tidak berjiwa dlam produksi barang, yang dipadukan dengan peran sentral mesin dalam proses produksi.

Modernitas telah membawa perubahan bagi masyarakat industri terutama bagi buruh perkebunan, modernitas yang terjadi saat ini 
Jurnal Pemikiran Sosiologi Volume 5 No. 2, 2018

Giddens dan Kapitalisme: Etika Kerja Buruh Karet di Perkebunan Sumatera Selatan

Rica Arvenia, Muhammad Fedryansyah, M. Fadhil Nurdin

mengakibatkan buruh perkebunan menjadi kehilangan harapannya, membuat buruh tidak semangat kerja. Modernitas pada dasarnya mengglobal hal ini terbukti pada beberapa karakteristik dasar utama institusi modern, termasuk pemisahan dan refleksivitas mereka. Globalisasi menyebabkan terjadinya modernitas, modernitas didukungi oleh aktor sebagai agen perubahan yang membawa orang-orang yang ada mengubah cara berfikir. Giddens menawarkan konseptualisasi ulang antara "mikro dan makro" berkaitan dengan cara bagimana hubungan interaksi dalam konteks pertemuan muka dilibatkan secara struktural dalam sistem-sistem perentangan ruang dan waktu yang luas. Teori strukturasi muncul berasal dari kekosongan teori aksi dalam ilmu-ilmu sosial (Giddens dalam Syahri, 2015). Fungsionalisme dan strukturalisme merupakan tradisi besar intelektual yang terkemuka dalam teori sosial sepanjang tiga atau empat puluh tahun yang lalu. Fungsionalisme dan strukturalisme jika dipelajari akar dari pemikiran ini berawal dari Durkheim, dalam membuat teri strukturasi Giddens juga Giddens juga membutuhkan beberapa term Strukturalisme dan Fungsionalisme. Teori strukturisasi berusaha mencari dan menggali titik temu antara agenstruktur atau makro-mikro. Giddens memang banyak meminjam gagasan-gagasan strukturalisme. Hal ini tampak dalam catatannya atas strukturalisme, yaitu: (a) Teori strukturalis menunjukkan pentingnya penciptaan ruang melalui perbedaan dalam proses konstitusi Bahasa dan masyarakat,

(b) pemikiran Strukturalis berupaya memasukan dimensi waktu ke dalam pusat analisis itu sendiri,

(c) pemikiran strukturalis menunjukkan bahwa "jarak dalam waktu" dalam beberapa aspek pentignya sama dengan "jarak etnografis",

(d) teori strukturalis menawarkan kemungkinan pemahaman yang lebih memuaskan tentang totalitas sosial dari pada yang ditawarkan oleh fungsionalisme,

(e) dalam teori strukturalisme ada upaya gerakan untuk melampaui dualism subjek/objek.

Menurut Giddens, individu adalah agen yang memiliki pengetahuan banyak (knowledgeable agen) dan kemampuan memahami tindakannya sendiri. Mereka bukan lapisan budaya atau opara penopang hubungan-hubungan sosial belaka, akan tetapi mereka adalah para aktor terampil yang memiliki pengetahuan yang banyak tentang dunia yang mereka geluti. Semua aktor sosial adalah teoritisi sosial dan harus seperti itu untuk menjaga agen-agen sosial yang sesungguhnya. Salah satu kontribusi khas dari fenomenologi adalah menunjukkan bahwa 
Jurnal Pemikiran Sosiologi Volume 5 No. 2, 2018

Giddens dan Kapitalisme: Etika Kerja Buruh Karet di Perkebunan Sumatera Selatan

Rica Arvenia, Muhammad Fedryansyah, M. Fadhil Nurdin

(f) beroperasinya kehidupan sosial terus menerus melibatkan 'kegiatan berteori',

(g) bahkan kebiasaan-kebiasaan yang paling bertahan alam atau normanorma yang paling mapan sekalipun melibatkan perhatian refleksif yang terus menerus dan mendetail.

Rutinitas merupakan elemen penting dalam kehidupan sehari-hari, setiap orang tentu harus mempunyai rutinitas, rutinitas seseorang dapat dilihat dari kepribadiannnya, rutinitas merupakan tindakan setiap hari atau kegiatan yang biasa dilakukan seseorang. Dalam teori Strukturisasi, pengetahuan pengetahuan dipahami adalam istilah keasadaran praktis sekaligus diskursif, dan harus setiap aktor individual hanyalah salah satu diantara sekian dalam masyarakat, harus diakui bahwa sesuatu yang diketahui oleh seseorang anggota masyarakat yang kompeten 'mengalami peragaman warna' di dalam konteks yang merentang melampaui konteks aktivitas sehari-hari.

Tindakan manusia dimulai dari pengawasan refleksif terhadap perilaku yang megacu pada sifat intensionalitas atau bertujuan perbuatan manusia aspek ini menekankan 'kesenjangan' sebagai proses. Kesenjangan semacam itu merupakan sifat tetap perilaku manusia. Dalam melakukan tindakan agen dibatasi oleh konsekuensi tindakan-konsekuensi tindakan yang tidak dikehendaki (unintended consequences of action). Konsekuensi yang tidak disengaja dapat menjadi kondisi-kondisi yang tidak diketahui sepanjang konsekuensi yang tidak disengaja tersebut merupakan pengembangan diri struktur yang akan memungkinkan tindakan selanjutnya (Giddens: 2005: 150). Membahas tetang modernitas yang terjadi saat ini gerak laju modernitas semakin kencang ketika sistem kapitalisme mulai tumbuh subur, salah satu indikasi bisa dilihat dari mulai menjamurnya perusahaan yang mempunyai alat-alat canggih dan mempunyai jaringan online, sehingga tenaga manusia yang dibutuhkan semakin kurang, kini perusahaan atau sistem industri dan usaha lainnya sudah mengarah ke system modern, menggunakan alat bantu seperti alatalat canggih yang dapat memudahkan system kerja yang ada. Dengan adanya teknologi modern industri seolah-olah tidak terlalu bergantung pada tenaga manusia sehingga pekerjaan menjadi sangat berharga, terkadang tidak perduli denan status dan jabatan seperti apa yang paling terpenting adalah bekerja untuk mendapatkan hasil guna memenuhi kebutuhan, persaingan dalam dunia kerja sangatlah banyak, sitem kapitalis semakin berkembang, sistem kapitalis merasa sangat bangga ketika orang-orang mmebutuhkan pekerjaan hal semacam ini dimanfaatkan oleh pemilik modal untuk mengusai tenaga 
Jurnal Pemikiran Sosiologi Volume 5 No. 2, 2018

Giddens dan Kapitalisme: Etika Kerja Buruh Karet di Perkebunan Sumatera Selatan

Rica Arvenia, Muhammad Fedryansyah, M. Fadhil Nurdin

manusia untuk bekerja dengannya, sistem seperti ini direproduksi dan dapat menjadi contoh yang tidak baik bagi generasi penerus.

\section{Metode Penelitian}

Kajian ini menggunakan pendekatan kualitatif. Metode yang digunakan adalah deskriptif yang bertujuan untuk menggali dan mengkaji kapitalisme dan etika kerja yang ada pada perkebunan karet di Sumatera Selatan. Peneliti mengumpulkan data awal dengan cara Analisis Dokumen yang berfungsi sebagai dasar bagi peneliti terkait permasalahan menurunnya harga karet dan masuknya kapitalisme pada sektor perkebunan karet sebagai dampak dari modernisasi atau perubahan struktur yang ada. Adapun sumber data yang digunakan dalam penelitian ini adalah beberapa dokumen terkait permasalahan perkebunan karet yaitu data yang didapat dari key informan perkembangan harga kebun karet 5 tahun terakhir Analisis data yang akan dilakukan dalam penelitian ini dilakukan secara bertahap dari reduksi data, penyajian data, hingga penarikan kesimpulan terkait hasil penelitian.

Teknik penelitian yang digunakan adalah wawancara mendalam kepada key informan (pemilik dari salah satu kebun karet yang ada di Sumatera Selatan dan buruh perkebunan) dan observasi pada perkebunan karet di Sumatera Selatan guna mengtahui keadaan secara langsung di perkebunan, keadaan yang dapat berpengaruh pada etika kerja buruh karet serta hubungan antara pekerja dan pemilik perkebunan dan masuknya kaum kapitalis. Unit observasi dalam penelitian ini adalah buruh tua dan buruh muda yang. Untuk pemilihan informan penelitian maka penelitian ini menggunakan sampling purposive dikarenakan sesuai dengan tujuan penelitian, Pemilihan informan dengan teknik ini bertujuan untuk mendapatkan data dari informan (Cresswel, 2010:97. Sugiyono,2009:25).

\section{Hubungan Kerja, Etika Kerja dan Kaitannya dengan Kapitalisme serta Modernitas}

Hubungan kerja dapat diartikan sebagai hubungan yang terjadi antara bagian-bagian atau individu-individu baik antara mereka di dalam organisasi maupun antara mereka dengan baik antara mereka di dalam organisasi maupun antara mereka dengan pihak luar organisasi sebagai akibat penyelenggaraan tugas dan fungsi masingmasing dalam mencapai sasaran dan tujuan organisasi (Ernawati, 2010). Hubungan kerja ada beberapa macam yaitu hubungan antara 
Jurnal Pemikiran Sosiologi Volume 5 No. 2, 2018

Giddens dan Kapitalisme: Etika Kerja Buruh Karet di Perkebunan Sumatera Selatan

Rica Arvenia, Muhammad Fedryansyah, M. Fadhil Nurdin

buruh, hubungan antara buruh dan atasan, dalam hubungan kerja juga tentunya ada aksi dan reaksi saling berkomunikasi satu sama lain.

Pada dasarnya hubungan kerja, yaitu hubungan antara pekerja dan pengusaha terjadi setelah diadakan perjanjian oleh pekerja dengan pengusaha dimana pekerja menyatakan untuk menerima upah, dan pengusaha menyatakan kesanggupannya untuk mempekerjakan pekerja dengan membayar upah. Di dalam pasal 50 Undangundang No. 13/2003 tentang ketenagakerjaan dijelaskan bahwa hubungan kerja terjadi karena adanya perjanjian kerja antara pengusaha dan pekerja. Hubungan kerja yang ada di sektor perkebunan karet merupakan hubungan kerja yang baik antar sesame buruh kebun dan pemilik perkebunan, hubungan kerja yang ada di perkebunan memang sangat baik karena orang yang bekerja diperkebunan memang saling membutuhkan dan saling mengerti keadaan satu sama lain sehingga bekerja di dalam perkebunan karet cenderung tidak ada persaingan yang begitu ketat akan tetapi persaingan sewaktu-waktu muncul karena hasil yang di dapatkan cenderung berbeda-beda sesuai dengan rajin atau tidak kita bekerja. Hubungan kerja juga tergantung pada pemliki perkebunan jika pemilik dari perkebunan mempunyai karakter yang baik akan dapat dengan mudah para buruh untuk menyesuaikan dalam bekerja.
Perjanjian kerja dibuat oleh karyawan dan pengusaha atau pimpinan perusahaan secara perseorangan. Perjanjian kerja merupakan suatu peristiwa yang terjadi ketika seseorang karyawan berjanji ketika seorang karyawan berjanji kepada perwakilan perusahaan yang saling berjanji untuk melaksanakan suatu kegiatan kerja (Subekti, 2002; Solimun, 2002; Aninditiya.et.al, 2015). Tujuan yang sangat penting dalma perjanjian kerja adalah syaratsyarat kerja yang diberikan oleh pemberi kerja harus ditaati dan dilaksanakan dengan baik oleh karyawan atau pekerja, dan karyawan berhak untuk menuntut haknya pada karyawan serta pemberi kerja harus melaksanakan kewajibannya pada karyawan begitupun sebaliknya.

Dasar-dasar yang ada pada perjanjian kerja yang harus diketahui oleh buruh atau pekerja kemudian harus dipahami oleh buruh atau pekerja dan pemberi kerja yang tetulis pada Undang-undang No 13 tahun 2003 sebagaimana yang dijabarkan berikut ini:

1. Pasal 5, perjanjian kerja dibuat secara tertulis maupun secara lisan.

2. Pasal 52 ayat (1) poin a adanya kesepakatan antara karyawan dan pemberi kerja untuk mengikat kedua belah pihak dan- menyepakati beberapa ketentuan yang harus disetujui.

3. Pasal 52 ayat (1) poin b, kedua belah pihak harus mampu atau cakap dalam melakukan perbuatan hukum

4. Pasal 52 ayat (1) poin c, pekerjaan yang diperjanjikan merupakan 
Jurnal Pemikiran Sosiologi Volume 5 No. 2, 2018

Giddens dan Kapitalisme: Etika Kerja Buruh Karet di Perkebunan Sumatera Selatan

Rica Arvenia, Muhammad Fedryansyah, M. Fadhil Nurdin

masalah pokok yang harus tertera dalam perjanjian kerja.

5. Pasal 52 ayat (1) poin $\mathrm{d}$, objek perjanjian harus legal tidak menyalahi peraturan perundang-undangan Republik Indonesia.

Hak buruh pekerja selalu melekat pada setiap orang yang bekerja dengan menerima gaji atau upah. Karena pekerjaannya dibawah perintah orang pemberi kerja maka pekerja perlu mendapatkan jaminan perlindungan dari tindakan yang sewenang-wenang dari orang yang membayar gaji. Terdapat 2 jenis hak buruh yaitu hak buruh sebagai individu dan hak buruh sebagai anggota serikat pekerja. Hak-hak nya tersebut termuat dengan jelas dalam Undang-undang No 13 Tahun 2003 tentang ketenagakerjaan. Hasil dari perjanjian kerja bersama yang biasanya berupa pemenuhan hak-hak dan kewajiban pekerja, serikat pekerja dan pengusaha, sehingga dari kesepakatan tersebut diharapkan pengusaha maupun serikat pekerja atau pekerja dapat melaksanalan dan merealisasikan dengan baik hak dan kewajiban mereka sehingga dapat tercipta hubungan kerja yang harmonis, rasa yang aman dan nyaman dapat menimbulkan kepuasan kerja, Perjanjian kerja pada sektor perkebunan karet hanya perjanjian sewajarnya saja perjanjian yang tidak terlalu terikat dan membuat para buruh merasa terbebani, perjanjian pada sektor perkebunan ialah bekerja tidak full time, bekerja menyadap pohon karet hanya di pagi hari makin pagi menyadap pohon karet makin banyak pula getahnya karena rata-rata tradisi menyadap pohon karet dilakukan pada pagi hari. Upah atau gaji yang diterima sesuai seberapa banyak yang ia dapatkan dan tergantung pada harga karet, pada perkebunan karet biasanya gaji bukan merupakan angka tetap yang diberikan oleh pemilik kebun sistem pembagian gaji biasanya di bagi-bagi dari total hasil penjualan karet, pembagian gaji juga tidak menentu terkadang mingguan bahkan bulanan, jika bulanan hasil getah mingguan diendapkan di dalam air atau biasanya di sungai untuk menambah berat dari getah karet sehingga penghasilan yang didapatkan bisa bertambah.

Indonesia adalah negara berkembang, sebagai negara berkembang Indonesia mempunyai jumlah penduduk yang luas. Bertambahnya jumlah penduduk setiap tahun sangat membuat pemerintah kesulitan dalam mengatur negara menjadi lebih baik, banyak program pemerintah belum terealisasikan. Jumlah penduduk yang bertambah setiap tahunnya berdampak pada persaingan kerja, bekerja merupakan kebutuhan setiap orang, bekerja di Indonesia banyak persaingan, jumlah lapangan pekerja yang sedikit tidak sesuai dengan jumlah penduduk Indonesia bahkan tidak bisa dipungkiri bahwa pekerja anak dan lansia masih terus mencari 
Jurnal Pemikiran Sosiologi Volume 5 No. 2, 2018

Giddens dan Kapitalisme: Etika Kerja Buruh Karet di Perkebunan Sumatera Selatan

Rica Arvenia, Muhammad Fedryansyah, M. Fadhil Nurdin

pekerjaan guna memenuhi kebutuhan sehari-

hari. Kebutuhan terus meningkat dan harga kebutuhan semakin mahal sehingga bagi rakyat kecil sangat sulit untuk memenuhi kebutuhannya. Buruh merupakan mereka yang bekerja pada usaha perorangan yang diberi imbalan baik secara harian, mingguan, bulanan sesuai dengan perjanjian ketika akan bekerja sebagai buruh.

Etika atau etos selalu ada dalam setiap perusahaan,industry, dan perkebunan (Messier dalam Archandar, 2010) etika kerja adalah sebagai suatu tingkatan dimana seseorang meyakini bahwa kerja keras merupakan sesuatu yang sangat peting dan bahwa uang yang berlebihan merupakan sesuatu yang dapat merusak. Etika kerja juga merupakan pelengkap perusahaan, etika kerja sangat penting dalam suatu organisasi dengan adanya etika kerja dapat membentuk nilainilai kerja dalam suatu organisasi. Etika kerja kerja juga dapat diartikan sebagai: "Ethics refers to a system or code of conduct based on moral duties and obligations that indicate how an individual should behave in society.

Ada dua macam etika yang harus dipahami bersama dalam menetukan baik atau buruknya perilaku seseorang.

1. Etika deskriptif yaitu etika yang berusaha meneropong secara kritis dan rasionalitas sikap dan perilaku manusia dan apa yang dikejar oleh manusia dalam hidup ini sebagai sesuatu yang bernilai. Etika deskriptif memberikan fakta sebagai dasar untuk mengambil keputusan tentang perilaku atau sikap yang mau diambil.

2. Etika normatif, yaitu etika yang berusahan menetapkan berbagai sikap dan pola perilaku ideal yang seharusnya dimiliki oleh manusia dalam hidup ini sebagai sesuatu yang bernilai. Etika kerja normative member penilaian sekaligus member norma sebagai dasar dan kerangka tindakan yang akan diputuskan.

Secara umum etika kerja mempunyai ketentuan yaitu, sikap dan perilaku, penampilan, cara berpakaian, cara berbicara, cara gerik, cara bertanya. Artinya adalah sikap dan perilaku selama bekerja harus baik dan sopan gunakan pakaian sewajarnya untuk bekerja karena bekerja sebagai buruh harus mentaati peraturan yang ada tidak bisa bertindak semaunya. Gerak gerik harus menunjukkan bahwa kualitas diri menjadi pandangan penting terhadap orang lain agar dapat penilaian yang baik, gunakan cara berbicara yang sopan ramah dan lantang agar dapat berkomunikais dengan baik antar buruh kebun dan pemilik kebun. Mempunyai pribadi yang baik merupakan kebiasaan yang dibawa dari rumah ke tempat bekerja, kepribadian seseorang dapat dilihat dari kebiasaannya, mempunyai sikap dan berprilaku yang baik di dalam perkebunan dapat menciptakan kenyamanan antar sesama buruh. Etika kerja yang ada kerja pada sektor perkebunan karet diperlukan agar dapat membentuk suatu 
Jurnal Pemikiran Sosiologi Volume 5 No. 2, 2018

Giddens dan Kapitalisme: Etika Kerja Buruh Karet di Perkebunan Sumatera Selatan

Rica Arvenia, Muhammad Fedryansyah, M. Fadhil Nurdin

kebisaan yang baik, membentuk sebuah sistem agar dapat diterapkan kepada buruh perkebunan, etika kerja biasanya dimulai dari pemilik perkebunan atau perusahaan agar dapat menjadi contoh yang baik bagi para buruh.

Sistem kapitalis biasanya ada pada sistem industri, kapitalis merupakan orang yang berkuasa, kapitalis juga dapat diartikan sebagai orang yang memiliki modal sehingga dapat mempengaruhi rakyat kecil untuk bekerja dibawah tekanan, pemilik modal (kapitalis) berusaha membeli lahan yang ada di pedesaan yang mempunyai potensi sumber mata uang sehingga masyarakat desa dipengaruhi agar dapat menjual lahan-lahan mereka kepada pemilik modal. Hal seperti ini membuat masyarakat desa menjadi merugi, masyarakat desa dengan pendidikan yang rendah mudah untuk dipengaruhi, masyarakat desa tidak berfikir panjang sebelum menjual lahannya. Kapitalisme adalah system produksi komoditi, berpusat pada relasi antara kepemilikan pribadi atas modal dan tenaga tanpa kepemilikan, hubungan ini membentuk sumbu utama dari sebuah sistem kelas. Usaha kapitalis tergantung setelah produksi untuk pasar yang kompetitif, harga menjadi sinyal bagi investor, produsen, dan konsumen sama.
Penanaman modal oleh sistem kapitalis hanya menjadi langkah-langkah yang dipergunakan untuk menguasai suatu wilayah, kapitalisme lokal dikuasai oleh pemilik modal yang ada di daerah tersebut. Kapitalisme lokal merupakan orang yang berkuasa dan memiliki modal dari zaman nenek moyang memang sudah memiliki kekayaan sehingga pada dasarnya kapitalisme lokal sangat berkuasa di daerah. Lahan perkebunan karet memang dibangun oleh pemilik modal atau orang kaya di Desa, harga karet memang pernah naik drastis sampai belasan ribu, beberapa tahun terakhir harga karet mulai tidak stabil dan menurun drastis mencapai Rp 6.500 hingga Rp 7.000. Petani karet mulai mogok berkebun, hasil yang didapat tidak sesuai dengan pengeluaran bahkan hasil tidak bisa untuk ditabung. Pada saat seperti ini sistem kapitalis mulai masuk dan mempengaruhi masyarakat desa untuk dapat menjualkan lahan yang mereka miliki yang nantinya akan di bangun usaha-usaha baru. Sebagai awal adanya kapitalisme ditengah-tengah masyarakat lokal didasarkan dari kapitalismeglobal yang secara perlahan melahirkan kapitalisme lokal di masyarakat setempat. Sehingga kapitalisme lokal akan terus dikembnagkan yang secara tidak andil yang akan ada diruang lingkup masyarakat.

Kapitalisme dalam suatu sistem kekuatan ekonomi yang berbasis pada kekuatan pasar dimana modal sebagai kekuatan utama. Kapitalisme juga tidak hanya menguasai 
Jurnal Pemikiran Sosiologi Volume 5 No. 2, 2018

Giddens dan Kapitalisme: Etika Kerja Buruh Karet di Perkebunan Sumatera Selatan

Rica Arvenia, Muhammad Fedryansyah, M. Fadhil Nurdin

sistem ekonomi, tetapi juga system sosial dan politik. Perangkat dari sistem itu dikendalikan dan dikuasai oleh sebagian individul tau pribadi. Semua system itu diatur melalui mekanisme harga dalam pasar untuk mengalokasikan sumber daya dimiiki. Sehingga, semua sumber daya yang ada dikendalikan oleh segelintir orang mengintervensikan melalui kekuatan pasar. Dalam sistem kapitalisme, penggunaan tenaga kerja dan modal diatur engan mekanisme harga sebagai perangkat koordinasi utamanya. Tiga sistem ekonomi ynag dominan pada saat ini adalah kapitalisme, sosialisme, dan gabungan dari kedua muara itu yakni kesejahteraan. Masing-masing telah mengalami revisi yang signifikan dari pada aslinya karena berbagai problem yang dihadapinya dalam kurun waktu yang lama dan juga karena perubahan-perubahan yang dilakukan untuk menyelesaikan persoalanpersoalan tersebut.

Kapitalisme dibentuk atas lantasan nilai (value yang sama yaitu materialismhendonisme yaitu segala kegiatan manusia di latar belakangi dan diorientasikan kepada segala sesuatu yang bersifat duniawi, dan dibangun diatas pandangan dunia yang sekuler yaitu memisahkan hal-hal yang bersifat spiritual dan material (agama dan dunia). Konsep kapitalisme dapat dikritisi melaui teori Giddens bahwa kapitalisme telah merubah struktur yang ada, baik buruknya system ada pada strukturnya merupakan pembentukan suatu kebiasaan yng terjadi oleh ajaran-ajaran luar masuk kedalam perkebunan dan membuat suatu peraturan baru sehingga struktur tidak diterapkan dengan baik, konsep ini menunjukkan bahwa "Kapitalisme" adalah suatu system ekonomi lainnya. Kapitalisme juga mengandung unsur pokok yang merupakan pandangan ekonomi dari keseluruhan tujuan, motif dan prinsip ekonomi. Motif dan prinsip ini didominasi oleh tiga gagasan yaitu: perolehan, persaingan, dan rasionalitas. Kapitalisme yang ada pada perkebunan karet berdampak pada semangat kerja buruh, buruh menggantungkan hidupnya dari hasil perkebunan yang ia harapkan selama bekerja. Gaji sangat penting untuk memenuhi kebutuhan terkadang buruh sudah bekerja menjalan semua perintah dan keinginan dari pemilik kebun akan tetapi sistem pinjam uang sangat sulit yang dirasakan buruh perkebunan memang meminjam ada batasan dan ada waktu tetapi tidak berjalan dengan baik. Kebutuhan memang datang sewaktu-waktu tidak bisa direncanakan sistem seperti ini disebut kapitalisme memperkerjakan buruh mengambil dari tenaga buruh dan hasil yang didapat tidak bisa mensejahterahkan buruh, tentu ada faktor penyebabnya yaitu kurangnya kepedulian antar sesama. Orang kaya cenderung memikirkan kepentingannya sendiri dibandingkan orang lain ketika buruh 
Jurnal Pemikiran Sosiologi Volume 5 No. 2, 2018

Giddens dan Kapitalisme: Etika Kerja Buruh Karet di Perkebunan Sumatera Selatan

Rica Arvenia, Muhammad Fedryansyah, M. Fadhil Nurdin

ingin bekerja biasanya ditawarkan perjanjian kerja yang sangat bagus memang bertahan hanya beberapa waktu saja setelah mulai tidak memperhatikan kewajibannya sebagai pemilik perkebunan, membahas soal penghasilan memang semua orang membutuhkan hidup bertetangga harus saling memperhatikan kesejahteraan buruh sangatlah penting.

Pada dasarnya semua manusia mempunyai proses untuk berubah, hampir setiap masyarakat terlibat dalam keadaan modernitas, modernitas memang tidak bisa dihindarkan oleh masyarakat proses ini akan muncul ketika masyarakat kehilangan individualnya, maka dengan mudah proses ini diterapkan dalam kehidupan masyarakat. Modernitas merupakan perubahan budaya, nilai-nilai, keadaan modernitas hampir tidak bisa dibatasi proses nya sangat luas seperti masalah sosial budaya, politik. Modernitas adalah proses transformasi (perubahan) ke suatu arah yang lebih maju dan meningkatkan berbagai macam aspek dalam kehidupan sosial. Secara yang sederhana modernitas dapat katakan sebagai proses dari trasional ke modern guna untuk meningkatkan kesejahteraan masyarakat (Rosana,.2011). Modernitas adalah kejadian saat ini didukung oleh sebuah perubahan yang mempengaruhi individu sehingga ketika proses itu sudah masuk ke dalam masyarakat biasanya masyarakat cenderung acuh dan tidak percaya diri, modernitas dapat membawa masyarakat pada dampak yang negatifjika modernitas dikekola oleh orang yang salah dan tidak diterapkan dengan baik.

Konsep modernitas dimaksudkan untuk seseorang agar dapat memperoleh cita-cita yang diinginkan, modernitas yang terjadi saat ini merupakan suatu proses secara sadar oleh suatu bangsa atau negara untuk menyesuaikan diri dengan konstelasi dunia pada suatu waktu tertentu dengan menggunakan kemjauan ilmu pengetahuan oleh karena itu usaha setiap konsep modernisasi selalu ada setiap zaman nya. Masyarakat Indonesia lebih condong ke budaya barat yang mana modernisasi ada pada sistem industri yaitu menggunakan proses-proses dari alat berat sehingga lapangan pekerjaan semakin hari semakin melemah keadaan yang seperti ini merupakan langkah yang tidak bisa dipertanggung jawabkan. Sistem industri modern mulai mengedepankan alat-alat dibandingkan tenaga manusia, alat seperti ini dibeli dari negara luar secara tidak langsung kita telah membantu perekonomian negara lain, masyarakat Indonesia mudah untuk dipengaruhi. Hampir setiap industri kini menuju ke konsep-konsep modern, masyarakat Indonesia kehilangan pekerjaan dan terkena dampak dari modernitas, masyarakat pedesaan hanya bergantung pada pekerjaan yang berbasis keterampilan seperti 
Jurnal Pemikiran Sosiologi Volume 5 No. 2, 2018

Giddens dan Kapitalisme: Etika Kerja Buruh Karet di Perkebunan Sumatera Selatan

Rica Arvenia, Muhammad Fedryansyah, M. Fadhil Nurdin

perkebunan karet, menyadap karet memang

masih menggunakan tenaga manusia akan

tetapi industri-industri karet sudah

mempunyai alat yang lebih canggih sehingga

keadaan ini memang dapat memudahkan

pekerjaan dan proses produksi dalam industri.

\section{E. Relasi Kerja Buruh Dan Perkembangan Harga Karet}

Beberapa tahun terakhir jumlah angka pekerja Indonesia meningkat. Badan Pusat Statistik (BPS) menginformasikan, bahwa angkatan kerja pada Februari 2017 sebanyak 131,55 juta orang, naik sebanyak 6,11 juta orang dibanding Agustus 2016 dan naik 3,88 juta orang dibanding Februari 2016. Namun demikian, penduduk bekerja di Indonesia pada Februari 2017 tercatat sebanyak 124,54 juta orang, atau naik sebanyak 6,13 juta orang dibanding keadaan Agustus 2016 dan naik sebanyak 3,89 juta orang dibanding Februari 2016.



Tabel.01 Perkembangan Harga Karet di Sumatera Selatan (Sumber: Data Primer /Hasil wawancara)

Sumatera Selatan terdapat sekitar 2500 desa yang mata pencaharian utama penduduknya adalah bertani karet; 2) Meningkatnya adopsi bibit karet unggul. Pada tahun 1980-an terdapat $40 \%$ petani yang menanam bahan tanam klon unggul (Hendratno \& Supriadi, 2011), sedangkan pada tahun 2010 jumlah petani yang mengadopsi klon unggul sudah mencapai $\quad 60-70 \%$ serta 3) banyak pembangunan pabrik pengolahan karet yang dapat menampung karet yang dihasilkan petani. Hingga tahun 2012 jumlah pabrik pengolahan karet yang berdiri dan beroperasi di Sumatera Selatan mencapai sebanyak 27 pabrik (Gabungan Pengusaha Karet Indonesia). 
Jurnal Pemikiran Sosiologi Volume 5 No. 2, 2018

Giddens dan Kapitalisme: Etika Kerja Buruh Karet di Perkebunan Sumatera Selatan

Rica Arvenia, Muhammad Fedryansyah, M. Fadhil Nurdin

Penurunan harga karet tersebut diduga telah memberikan berbagai dampak terhadap kondisi sosial ekonomi petani karet khususnya di Sumatera Selatan dikarenakan hampir 800 ribu KK atau 46\% penduduk sumatera selatan menggantungkan hidupnya dari komoditas karet (Direktorat Jenderal Perkebunan [Dirjenbun], 2013; BPS Sumsel, 2012). Penurunan harga karet memang menjadi masalah bagi masyarakat perkebunan, masyarakat perkebunan menggantungkan pendapatan dari hasil panen karet. Harga yang tidak stabil memang mnurunkan semangat kerja, harga karet Indonesia menjadi salah satu dampak dari produksi berlebihan dari Negara tetangga Malaysia dan Thailand dibuktikan dengan hasil dari BPS Indonesia.

Provinsi Sumatera Selatan memiliki berbagai macam potensi sumber daya alam (SDM) baik itu dari darat dan air salah satu hasil yang dari darat yaitu hutan yang luas dan lebat, serta berbagai jenis tambang seperti batubara, dan minyak. Selain itu juga terdapat sungai yang luas sehingga berbagai macam kekayaan alam yang terkandung didalamnya, untuk mengoptimalisasikan sumber kekayaan alam secara menyeluruh dan terpadu harus memperhatikan keseimbangan dan kelestarian kehidupan.

Sumatera Selatan kaya akan hasil alamnya mayoritas penduduk di pedesaan bekerja disektor pertanian dan perkebunan, masyarakat perkebunan mempunyai tingkat pendidikan rendah sehingga sangat cocok jika bekerja di sektor hasil perkebunan. Kebun karet adalah salah satu kebun ungggulan yang ada di Sumatera Selatan menjadi kebanggan bagi masyarakat perkebunan, produksi besarbesaran pernah di alami oleh sektor industri karet yang ada di Sumatera Selatan. Hasil karet pernah menjadikan pendapatan ekonomi buruh dan pemilik perkebunan mejadi Berjaya pada masanya kini harga karet tidak stabil dan membuat pendapatan menurun. Kebuutuhan yang semakin meningkat membuat buruh menglami kesusahan untuk mencapi pendapatan lebih sehingga menjadikan buruh perkebunan untuk melakukan pinjaman terlebih dahulu kepada pemilik dari perkebunan karena harga yang menurun membuat kerja semakin keras dan pendapatan menjadi tidak pasti. 
Jurnal Pemikiran Sosiologi Volume 5 No. 2, 2018

Giddens dan Kapitalisme: Etika Kerja Buruh Karet di Perkebunan Sumatera Selatan

Rica Arvenia, Muhammad Fedryansyah, M. Fadhil Nurdin

\begin{tabular}{|c|c|c|c|c|c|}
\hline N & $\begin{array}{c}\text { Provinsi } \\
1\end{array}$ & $\begin{array}{c}\text { Perkeb- } \\
\text { unan } \\
\text { Rakyat }\end{array}$ & $\begin{array}{c}\text { Perkeb- } \\
\text { unan } \\
\text { Negara }\end{array}$ & $\begin{array}{c}\text { Perkeb- } \\
\text { unan } \\
\text { Swasta }\end{array}$ & $\begin{array}{c}\text { Jumlah } \\
/\end{array}$ \\
\hline 1 & $\begin{array}{c}\text { Sumatera } \\
\text { Selatan }\end{array}$ & 889.262 & 11.749 & 46.879 & 947.89 \\
\hline 2 & $\begin{array}{c}\text { Sumatera } \\
\text { Selatan }\end{array}$ & 867.589 & 11.805 & 49.202 & 928.596 \\
\hline 3 & $\begin{array}{c}\text { Sumallholder } \\
\text { Selatan }\end{array}$ & 879.105 & 11.951 & 51.016 & 2 \\
\hline
\end{tabular}

Tabel 02. Produksi Karet berdasarkan Provinsi dan Kategori Pertanian (Sumber: BPS Indonesia 2014-206)

Buruh adalah bagian dari masyarakat yang perlu disejahterakan secara sosial, politik, budaya dan ekonomi. Keberadaan buruh di Indonesia sudah ada sejak zaman penjajahan belanda Sedangkan pergerakan buruh semenjak 1987, yaitu serikat buruh guru-guru bangsa belanda di Indonesia. Serikat pekerja tersebut adalah NIOG (Netherland Indies Onderw Genooth) (Randi.2017). Buruh menurut undang-undang No. 22 Tahun 1957 tentang penyelesaian perselisihan perburuhan, pasal 1 ayat a ditulis sebagai berikut: "Buruh ialah barang siapa bekerja pada majikan dengan menerima upah".
Menurut undang-undang No.13 Tahun 2003 tentang ketenagakerjaan, buruh disamakan dengan pekerja. Hal itu dapat dibaca seperti tertulis pada pasal 1 ayat 3 yang berbunyi: "Pekerja atau buruh adalah setiap orang yang bekerja dengan menerima upah atau imbalan dalam bentuk lain. Istilah buruh di dalam Kamus Besar Bahasa Indonesia (KBBI) adalah orang yang bekerja untuk orang lain dengan mendapat upah atau sama dengan pekerja. Mengenai buruh itu di dalam KBBI lebih lanjut dibedakan adanya tida klasifikasi buruh, yaitu pertama buruh kasar yang berarti buruh menggunakan tenaga fisiknya karena tidak mempunyai keterampilan di bidang tertentu, dan ketiga buruh terlatih, yaitu buruh yang sudah dilatih untuk keterampilan tertentu (Utomo, 2005).

\section{F. Kesimpulan}

Budaya modernitas yang terjadi saat ini merupakan dampak dari berubahnya individu yang dipengaruhi oleh budaya luar sehingga masyarakat kehilangan individualism, agen dan agensi sangat berperan penting dalam proses mempengaruhi dan dipengaruhi. Masyarakat pedesaan memang sangat mudah dipengaruhi oleh orang luar yang berniat untuk menguasai suatu wilayah, ketika masyarakat sudah dipengaruhi dan 
Jurnal Pemikiran Sosiologi Volume 5 No. 2, 2018

Giddens dan Kapitalisme: Etika Kerja Buruh Karet di Perkebunan Sumatera Selatan

Rica Arvenia, Muhammad Fedryansyah, M. Fadhil Nurdin

masyarakat luar sudah mempengaruhi maka suatu sistem telah berubah, kebisaan, budaya, nilai-nilai sudah mulai ditinggalkan. Perubahan seperti ini membawa dampak buruh terhadap perkembangan masyarakat sistem yang telah terjadi seketika berubah. Pemilik modal mepunyai tujuan untuk menguasai suatu wilayah agar dapat memiliki kekuasaan dan semua orang harus ada dibawah kekuasaannya sehingga pemilik modal dapat mengatur orang yang bekerja kepadanya.

Agen dan agensi selalu ada sehingga agen dan agensi dangat erat kaitannya dengan kapitalisme, ketika hal ini terjadi maka etika kerjapun dapat berubah dan tidak bisa dikendalikan, buruh yang bekerja pada perkebunan karet menjadi lemah dan tidak termotivasi bekerja karena keinginannya tidak tepenuhi dan tidak sesuai dengan apa yang ia harapkan, bekerja sebagai buruh merupakan pekerjaan yang mengabdi pada pemilik dari perusahaan sehingga buruh harus mengikuti aturan kerja yang ada, perubahan struktur disebabkan oleh agen dan agensi, agen dan agensi tidak bisa dihindarkan mereka terbentuk berdasarkan kebiasaankebiasaan budaya luar yang masuk sehingga dapat merubah secara perlahan. Hal seperti ini berdampak pada buruh perkebunan karet, struktur sangatlah penting ketika struktur berubah semua yang terjadi tidak bisa dikendalikan dengan baik, struktur yang baik merupakan suatu contoh, perubahan struktur dan dampak dari modernitas telah merenggut harapan buruh perkebunan.

\section{Referensi}

Buku

Creswell J, W. 2010. Desain Penelitian: Pendekatan Kualitatif, Kuantitatif,dan Mixed (Edisi Ketiga) (Achmad Fawaid, Penerjemah). Yogyakarta:Pustaka Pelajar.

Giddens, A. 1984. Teori Strukturasi Dasardasar pembentukan struktur sosial masyarakat. Terjemah oleh Maufur dan Daryanto. 2010. Yogyakarta: Pustaka Pelajar

Giddens, A. 2005. Konsekuensi-konsekuensi Modernitas. Yogyakarta: Kreasi Wacana

Ritzer,G. 2012. Teori Sosiologi Dari Sosiologi Klasik Sampai Perkembangan Terakhir Posmodern. Yogyakarta: Pustaka Pelajar.

Subekti. 2002. Hukum Perjanjian. Jakarta: Intermasa.

Sugiyono. 2009. Metode Penelitian Kuantitatif Kualitatif Dan R\&D. Bandung: Alfabeta.

Jurnal

Aninditiya, et.al. 2015. Pengaruh Perjanjian Kerja dan Perjanjian Kerja Bersama Terhadap Hak-hak Karyawan dan Kepuasan Kerja. Universitas Brawijaya. Jurnal administrasi Bisnis Vol 28 No 1.

Archandar,T,A. 2010. Pengaruh Etika Kerja Terhadap Keterlibatan Kerja Dan Implikasinya Terhadap Komitmen Kerja, Kepuasan Kerja Dan Kinerja 
Jurnal Pemikiran Sosiologi Volume 5 No. 2, 2018

Giddens dan Kapitalisme: Etika Kerja Buruh Karet di Perkebunan Sumatera Selatan

Rica Arvenia, Muhammad Fedryansyah, M. Fadhil Nurdin

Pekerja Pada Karyawan Lembaga

Pendidikan Tinggi.Jurnal Management

Dan Pemasaran Jasa Vol 3 No 2.

Ernawati. 2010. Pengaruh Hubungan Kerjadan Lingkungan Kerja Terhadap Kinerja Pegawai Dengan Motivasi Kerja Terhadap Kinerja Pegawai Dengan Motivasi Kerja Sebagai Variabel Moderating. Jurnal Ekonomi Dan Kewirausahaan Vol 10 No 2.

Hendratno, S., \& Supriadi, M.(2011). Peningkatan Produktivitas Kebun Melalui Peremajaan Dan Penanaman, Lokakarya Karet Nasional. Jakarta, Indonesia: Pusat Penelitian Karet.

Hidayat, Dedy N., "Jurnalis, Kepentingan Modal, dan Perubahan Sosial", dalamDedy N. Hidayat, et.al, Pers dalam "Revolusi Mei": Runtuhnya Sebuah Hegemoni , Gramedia Pustaka Utama, Jakarta, 2000

Randi. 2017. Buruh Vs Perusahaan (Konflik Buruh/Pekerja Driver Go-Jek Dengan PT Go-Jek Indonesia).Jurnal Social Network Vol.7 No.2

Rosana, E. 2011. Modernisasi dan Perubahan Sosial. Jurnal Tapis Vol 7 No 12.

Utomo,S,I. 2005. Suatu Tinjauan Tentang Tenaga Kerja Buruh Di Indonesia. Jurnal The Winners Vol 6 No 1.

Solimun. 2002. Multivariate Analysis Structural Equation Modeling (SEM) Lisrel And Amos. Malang FMIPA Universitas Brawijaya.

Spaargaren. G. 2008.Sociology, Environment, And Modernity: Ecological Modernization As A Theory Of Social Change. Society \& Natural Resources: An International Journal Vol 5.
Sumber Internet

"Statistik Perkebunan Indonesia. 2016. Karet. Direktorat Jenderal Perkebunan Indonesia." http://ditjenbun.pertanian.go.id/tiny mcpuk/gamar/file/statistik/2016/KA RET\%202014-2016.pdf. Diakses pada 26 juni 2018. 